and appreciation of scientific method and outlook, especially in relation to social progress". Further details may be obtained from the Scientific Film Association, 34 Soho Square, London, W.1.

\section{Annual Reviews of Psychology and of Physical Chemistry}

AN "Annual Review of Psychology" is to be published under the auspices of Annual Reviews, Inc., Stanford, California, the first volume to appear early in 1950. Prof. Calvin P. Stone and Donald W. Taylor, of Stanford University, will serve as editor and associate editor, respectively. The editorial committee will consist of the following: John E. Anderson, Institute of Child Welfare, University of Minnesota; John G. Darley, University of Minnesota; Clarence H. Graham, Columbia University ; Carl I. Hovland, Yale University; James G. Miller, University of Chicago. The subject-matter of each volume will consist of critical appraisals of research proceeding in the major divisions of the field. Subjects of greatest activity will be reviewed annually, while those of lesser activity, together with any topics which encompass small divisions of the field, will be reviewed biennially.

Organisation of an "Annual Review of Physical Chemistry" of a similar type, operating under the same editorial policies and characterized by a corresponding recurring list of topics, is also announced by Annual Reviews, Inc. This will be edited by Prof. G. K. Rollefson, of the University of California, Berkeley, and will be directed in the selection of topics and authors by an editorial committee consisting of Henry Eyring, University of Utah; George Glockler, State University of Iowa ; W. F. Libby, University of Chicago ; J. W. Williams, University of Wisconsin; and E. Bright Wilson, jun., Harvard University. The first volume will also appear in 1950. Annual Reviews, Inc., is a nonprofit corporation which was first constituted in 1932 to publish the "Annual Review of Biochemistry". Since then it has initiated the "Annual Review of Physiology" (jointly with the American Physiological Society) and the "Annual Review of Microbiology".

\section{Zoological Society of India}

THE following have been elected members of the Executive Council of the Zoological Society of India : President, Dr. S. L. Hora ; Vice-President, Prof. D. R. Bhattacharya; Secretary, Dr. M. L. Roonwal; Editor, Prof. K. N. Bahl; Treasurer, Dr. B. S. Chauhan; Members, Dr. K. Panikkar, Prof. M. A. Moghe, Dr. B. N. Chopra, Dr. Bhattacharya, Dr. G. D. Bhalerao, Dr. D. V. Bal, Dr. T. J. Job. It is intended to bring out the first volume of the Journal of the Zoological Society of India this year. Papers intended for publication, which should be original contributions or critical reviews of current researches not published elsewhere, should be sent either to the Editor (at the Zoology Department, Lucknow University, Lucknow) or to the Secretary (at the Zoological Survey of India, Banaras Cantt., U.P.).

\section{University of Glasgow}

The University Grants Committee is supporting the development of electrochemistry in the University of Glasgow; and Dr. J. C. James, at present at Battersea Polytechnic, London, has been appointed lecturer in chemistry under this project. Similar support is to be given to zoological taxonomy. Other recent appointments in the University of Glasgow are: Mrs. Rhoda M. Ainley, assistant in anatomy; J. Highet, lecturer in sociology; A. W. Sloan, lecturer in physiology; Bruno Toushek, a Nuffield fellow in physics; Mrs. Jean A. Wapshaw, part-time assistant in biochemistry; and A. Williams, lecturer in geology (with a year's leave of absence while holding a Commonwealth fellowship).

Work has been begun on the final portion of the new Chemistry Department at Glasgow, and on the building which is to house the $300-\mathrm{MeV}$. synchrotron. A $30-\mathrm{MeV}$. instrument is already in operation in the Department of Natural Philosophy.

\section{Announcements}

Prof. T. DALLING, director of the Veterinary Laboratory of the Ministry of Agriculture and Fisheries at New Haw, Weybridge, has been appointed chief veterinary officer to the Ministry from August 21 on the retirement of Sir Daniel Cabot, who has reached the age of sixty. Sir Daniel Cabot's services will be retained part-time in a temporary capacity in connexion with certain international veterinary organisations.

Mr. Arfred Eastham, chief officer of the Official Seed Testing Station since 1923, retired on June 30 and the Council of the National Institute of Agricultural Botany has appointed Mr. C. C. Brett to this post. Mr. Brett has been senior assistant to the chief officer since 1922, and during the past eighteen months has been seconded as executive officer of the Seed Production Committee.

THE following have been appointed to readerships in the University of Edinburgh : Mr. E. G. Dymond (natural philosophy), Dr. W. L. Edge (mathematics), Dr. Alexander Nelson (botany) and Dr. E. G. V. Percival (chemistry).

THE autumn meeting of the Deutsche Physikalische Gesellschaft in der Britischen Zone will take place at Clausthal-Zellerfeld/Harz during September 9-12.

THE fourth Commonwealth Mycological Conference will be held at the Imperial College of Science and Technology, South Kensington, during July 19-24. Plant pathologists from all parts of the British Empire will be present, and the topics to be discussed include the control of virus diseases, with special reference to swollen shoot of cacao, measures to be taken to avoid the transmission of seed-borne parasites through the seed, the certification of healthy planting material of certain vegetatively produced crops, new developments in fungicides, including their application from the air, and forest pathology.

Ar the annual general meeting of the Institute of Welding on June 30 , the following were elected honorary officers for 1948-49: President, Dr. J. H. Paterson; Vice-President, O. V. S. Bulleid; Honor. ary Treasurer, W. E. Harriss.

THE Governing Body of the Imperial College of Science and Technology has decided that the schemes for the international exchange of students during summer vacations, initiated by its Vacation Work Committee in 1946, shall be broadened in 1949 to include university students from other colleges in Great Britain. The exchange is operated through the recently established International Association for the Exchange of Students for Technical Experience, which at present includes Belgium, Czechoslovakia, Denmark, Finland, France, Netherlands, Norway, Sweden and Switzerland. 